\title{
The Effect of Feeding by the Channel Catfish (Ictalurus punctatus) on the Benthic Invertebrate Community in the Ponds
}

\author{
Martin M. Matute (Corresponding author), Yvonne A. Manning \& Mariam I. Kaleem \\ Department of Biology, University of Arkansas, 1200 N. University Dr., Pine Bluff, Arkansas 71601, USA
}

Tel: 1-870-575-8851_E-mail: matutem@uapb.edu

Received: January 30, 2012 Accepted: February 13, 2012 Online Published: May 9, 2012

doi:10.5539/jas.v4n6p267

URL: http://dx.doi.org/10.5539/jas.v4n6p267

\begin{abstract}
The impact of fish feed on benthic invertebrates in channel catfish (Ictalurus punctatus) ponds was investigated. Benthic samples were collected from 10 catfish ponds, five in which fish were fed and five in which fish were not fed. The fed and unfed ponds were identical in design, management history and stocking density. Four benthic composite samples were collected from each pond monthly for three months and the invertebrates extracted and $\mathrm{pH}$ values determined. Fish feeding significantly reduced invertebrate taxa, abundance and the $\mathrm{pH}$ in fed ponds as compared to the unfed ponds. The mean $\mathrm{pH}$ in fed and unfed ponds was respectively 6.38 and 7.59 ; this represents an approximate 71 fold difference. Differences in the benthic invertebrate community seem therefore to be associated with $\mathrm{pH}$ levels. Fish feed reduced the populations of certain catfish parasites and this could partly account for the increased fish yield in fed ponds. Ecologically, the results reveal that fish feeding has a reductive effect on invertebrate taxa richness and taxa abundance. The results of this investigation seems to suggest fish feeding has a disruptive effect on the natural ecological functions and processes ascribed to benthic invertebrates, by significantly reducing their abundance, taxa richness, and altering the hydrogen ion concentration of the benthic environment.
\end{abstract}

Keywords: Catfish ponds, Fish feed, pH, Invertebrate populations, Ecological functions

\section{Introduction}

Farmed raised channel catfish (Ictalurus punctatus) is a significant and important component of the fishery sector in the Arkansas Delta, USA. To increase catfish production, different rates and frequencies of feeding are used. Channel catfish raised in ponds are typically fed daily to apparent satiation to obtain maximum growth (Robinson \& Rushing, 1994). A feeding study of Booth et al. (2008) indicated that optimum to maximum weight gain and feed conversion ratio in juvenile snapper can be achieved by feeding fish to apparent satiation twice per day. Another study by Wang et al. (1998) with hybrid sunfishes (Lepomis cyanellus and L. macrochirus) in which the fishes were fed to satiation at one of four frequencies concluded that fish fed the higher frequencies showed the greatest consumption and growth rates.

Clearly feeding fish in ponds increases productivity. What is not clear is the impact that fish feeding has on the invertebrate community of the ponds. There is paucity of literature on invertebrates in freshwater culture ponds and the effects of fish feed on these aquatic animals. However, previous investigations in mariculture ponds seem to suggest that supplemental feeding and pond fertilization, increases benthic invertebrate populations (Perschbacher \& Strawn, 1984; Stahl, 1979; Fair \& Fortner, 1981).

The objectives of this study were as follows a) to document the invertebrates of freshwater channel catfish ponds in the studied site, b) to determine the impact of fish feed on the abundance and taxa richness of invertebrates in studied ponds, and c) to ascertain the potential implications of fish feed on natural ecological processes.

The hypotheses for this investigation are therefore as follows a) that fed ponds will record significantly higher populations of invertebrates as compared to non-fed ponds, b) fed ponds will record higher invertebrate taxa richness, and c) that fed ponds will better support natural ecological processes.

\section{Materials and Methods}

The fish ponds studied were located in the Jefferson County of the Arkansas Delta. Jefferson County soils are described as mostly poorly drained, $\mathrm{pH}$ 6.6-7.3, and organic matter content of 0.5-4.0 (Scott et al., 1998; Ferguson, 1920).

A total of 10 identical commercial fish ponds were investigated, five fed and five non-fed. The experimental channel catfish (I. punctatus) ponds were approximately 4.8 ha in surface area and approximately $1.2 \mathrm{~m}$ deep. Each 
pond was stocked at a rate of approximately 1, 000 fingerlings per hectare. Fed ponds were fed at an approximate rate of $45.4 \mathrm{~kg} / \mathrm{ha} / \mathrm{d}$ with $32 \%$ floating pellets during warm weather (above $21^{\circ} \mathrm{C}$ ). These ponds were fed for up to 12 times during the summer. In the winter, there was scanty feeding periods when the weather was relatively warm.

Benthic samples were collected using a corer sampler as previously described (Matute et al., 2009). Basically, the sampler was a $1.5 \mathrm{~m}$ long PVC cylindrical tube with a core diameter of $8.5 \mathrm{~cm} ; 30 \mathrm{~cm}$ from the distal end was perforated with drain holes and the core of the PVC tube contained a $1.75 \mathrm{~m}$ long wooden plunger to which was attached a PVC disc of diameter $8.2 \mathrm{~cm}$ at the distal end.

Benthic samples were collected from each pond for three months, December to February. Samples were collected every four weeks. Four composite samples were collected from each pond during each sampling period. Six corer subsamples constituted one composite sample. Each composite sample was collected from one of the four corners of the pond. Samples were collected $1.5 \mathrm{~m}$ away from the shore of each pond. Samples were collected at a core depth of $15-20 \mathrm{~cm}$.

In the laboratory, each composite soil sample was mixed, $50 \mathrm{~mL}$ was used for $\mathrm{pH}$ determination, and $100 \mathrm{~mL}$ was used for the recovery of invertebrates. Invertebrates were recovered using a combination of sieving, decanting and Baermann funnels (Barker, 1985). A $100 \mathrm{~mL}$ subsample was transferred onto a container with $10 \mathrm{~L}$ of water. Clumps of the samples were dissolved manually. This mixture was homogenized, passed through a 60 um and then through a 400 um mesh sieve. Each process was decanted. Macroscopic invertebrates trapped by the $60 \mathrm{um}$-mesh sieve were collected and passed through the $400 \mathrm{um}$ mesh sieve. The retained sample by the $400 \mathrm{um}$ mesh sieve was then transferred onto a Baermann funnel assemblage and incubated for 72 hours. After the incubation period, $15 \mathrm{~mL}$ of each sample was tapped and subjected to qualitative and quantitative analysis (Ferris \& Matute, 2003). Invertebrates collected by the 60 um mesh and those collected via the Baermann funnels, were combined. An unpaired t-test was used to analyze the data.

\section{Results and Discussion}

Samples for this investigation were collected for three months, December through February. In both treatments i.e fed and unfed ponds no significant difference was recorded between months, for all taxa of invertebrates recovered.

Fish Feeding and Benthic Invertebrate Populations: Invertebrates are part of aquatic natural foods and it has been reported that their abundance was increased through pond fertilization and / or supplemental feeding (Stahl, 1979; Fair \& Fortner, 1981; Perschbacher \& Strawn, 1984; Rubright et al., 1981). However, we found that unfed ponds recorded significantly higher invertebrate abundances than fed ponds. A significant reduction in invertebrate populations as recorded in this investigation may be an indicator of inhospitable benthic conditions in fed ponds.

For all the taxa, there was a significant difference between the fed and unfed ponds in terms of their numeric abundance (table 1). For the genus Physa, this difference was significant $(\mathrm{P}<0.05)$, while for the rest of the taxa, this difference was highly significant $(\mathrm{P}<0.001)$. Without exception, unfed ponds recorded significantly higher molluscan populations than the fed ponds.

The ecological significance of aquatic mollusks includes excellent water quality indicators, important and vital natural food sources, water filtration, and deposit feeders (Johnson, 2009; Liang \& Wang, 2001; Strayer et al., 1994). A significant loss of benthic biomass as recorded in this investigation may result in large alterations of ecosystem processes and functions.

Seven Arthropodan families were recovered (table 1) but only three were common to both fed and unfed ponds. They were the Argulidae, Candoniidae, and Cyclopidae. There was no significant difference $(\mathrm{P}<0.2)$ between fed and unfed ponds in their Macrocyclops populations. However, there were a significant difference between the fed and unfed ponds in their Argulus $(\mathrm{P}<0.01)$ and Candona $(\mathrm{P}<0.001)$ populations. In each case, the unfed ponds recorded significantly higher populations than the fed ponds.

The Arthropoda families that were not common to both treatments were the Lernaeidae, Chironomidae, Ceratopogonidae, and Hydrachnidae. With the exception of the Lernaeidae that was only recovered in the fed ponds, the remaining three families were absent in the fed ponds and present in the unfed ponds. In summary, higher populations of aquatic Arthropods were extracted from the benthic samples of the unfed ponds as compared to the fed ponds.

Argulids are external parasites and disease vectors of fish (Sutherland \& Whittrock, 1986). Their significant reduction by fish feed therefore has a beneficial effect. The main ecological functions ascribed to the Cadoniidae ostracods are herbivores, detrivores and prey, while the copepods are reported to occupy three trophic positions in 
the food chain-detrtivore, herbivore, and carnivore (Adrian, 1991; Williamson \& Reid, 2001). The significant population reduction of the Cadoniidae and Cyclopidae in the fed ponds therefore deprives this ecosystem of the ecological processes and functions attributed to these invertebrates. Furthermore, the absence of the Chironomidae, Ceratopogonidae, and Hydrachnidae in fed ponds as compared to the unfed ponds, seems to suggest that fish feeding results in habitat alteration such that certain invertebrate taxa are eliminated. The Hydrachnidae are the most diverse and ecologically important group of freshwater arachnids. As one of the dominant groups of arthropods in many freshwater habitats, water mites have integral roles in the organization and regulation of freshwater communities (Smith et al., 2001). Unlike the unfed ponds, the fed ponds in this investigation did not benefit from these ecological functions provided by the water mites because they were not recorded in the fed ponds.

Four annelid families were recovered but only Hirudinidae was recovered from the unfed ponds, while the other three taxa were common for both treatments (Table 1). For the common taxa recovered, the difference in their population densities was highly significant $(\mathrm{P}<0.001)$. The Aeolosomatidae and Lumbriculidae were higher in the unfed ponds while the Enchytraeidae was higher in the fed ponds.

Aeolosomatidae are agents of sludge reduction (Peng et al., 2006) and the lumbricids and other invertebrates are thought to be responsible for most of the phosphorus released from aerobic sediments in Lake Michigan, USA (Garner et al., 1981). Chatarpaul et al. (1979) showed that worms (including the Limbricidae) accelerated nitrogen loss from coarse streams sediments, indicating their importance in rivers as well as lakes. These ecologic functions of the Aeolosomatidae and Lumbriculidae are significantly reduced in fed catfish ponds as compared to the unfed ponds. The Enchytraeidae are litter transformers. They build holorganic structures (their fecal pellets) that serve as incubators for microbial activities. In these pellets, mineralization may be enhanced in short periods, but in the long term, relatively compact structure that limits aeration and water storage as well as accumulation of resistant humidified molecules may result in a significant decrease of mineralization, lasting as long as the structure's integrity is maintained (Russom et al., 1993; Toutain et al., 1982). Evidently, an abundance of the Enchytraeidae is a hindrance to the long term key ecological process of mineralization. In this investigation, feeding in catfish ponds significantly increased the population of Enchytraeus as compared to the unfed ponds.

For the Gastrotricha, Rotifera, and Tardigrada, only the Chaetonotidae was common to both treatments. The population density of the Chaetonotidae was significantly higher in the unfed ponds than fed ponds $(\mathrm{P}<0.001)$. The Collothecidae and Macrobiotidae were only recovered from the unfed ponds. It is likely they simply represent fortuitous collections. Previously, Gastrotrich density and species richness was positively correlated with habitat productivity and unpolluted waters (Kisielewski, 1986; Hummon, 1987). Furthermore, Rotifers have been described as generalist suspension feeders (Walz, 1997). They consume a wide variety of both plant and animal prey, including large algae and small ciliates. On the other hand, Eutardigrades are hypersentive to low oxygen levels and also require a habitat with suitable and sufficient food (Nelson, 2001). In summary, for the phyla Gastrotricha, Rotifera, and Tardigrada, unfed ponds recorded higher populations than fed ponds.

Fish feeding and Taxa Richness: In terms of taxa richness, unfed ponds recorded the same number or more than the fed ponds (Table1). For example, phylum Mollusca nine-taxa unfed ponds versus nine-taxa fed ponds; Arthropoda six-taxa unfed ponds versus four-taxa fed ponds, etc. Thus a total of seventeen invertebrate taxa were recovered from fed pond samples versus twenty-two taxa from the unfed pond samples. Clearly, the unfed ponds recorded higher taxa numbers than the fed ponds. This difference was significant $(\mathrm{P}<0.05)$. This observation suggest that fish feed in catfish ponds have a reductive effect on taxa richness.

The Effects of pH: Unfed pond samples recorded a mean $\mathrm{pH}$ for January through March of 7.65, 7.65, and 7.48 respectively versus $6.38,6.52$, and 6.24 respectively for the fed pond samples. The mean $\mathrm{pH}$ for the entire sampling period was therefore 7.59 (alkaline) versus 6.38 (acidic) respectively for the unfed and fed pond samples. This represents an approximate 71 fold difference between the two treatments.

As soil acidity increases, the proportion of exchangeable $\mathrm{Al}^{3+}$ increases and $\mathrm{Ca}^{2+}, \mathrm{Na}^{+}$, and other cations decrease. Such changes bring about nutrient deprivation in plants and microorganisms and also aluminum toxicity (Smith \& Smith, 2001). This investigation confirms that populations of microorganisms (and also the macro organisms), were reduced by acidic conditions. It would seem acidic conditions caused habitat alterations in the fed pond ecosystem resulting in an inhospitable terrain for certain invertebrate taxa (e.g, Macrobdella, Pseudobiotus, Unionicola) and /or barely making the aquatic habitat conducive enough for existence with significantly lower populations as compared to the unfed ponds (e.g, Probythinella, Candona, Lumbriculus).

It is not known why fed pond samples were acidic. It could however be due to the introduced fed and /or large amounts of waste produced by the larger number of fishes in the fed ponds. Previously, Matute et al. (2009) reported that benthic samples from partially fed fish ponds recorded higher populations of nematodes than fully fed ponds. This investigation corroborates this earlier one. 


\section{Conclusion}

A total of 22 benthic invertebrate taxa were recovered from the I. punctatus ponds investigated. Except for the Aeolosomatidae, the unfed ponds recorded significantly higher invertebrate population abundances than the fed ponds. Also the fed ponds had a significant reductive effect on taxa richness as compared to the unfed ponds. The greater acidic nature of the fed ponds as compared to the unfed ponds is thought to be responsible for the observed reductive effects associated with the fed ponds. Fed ponds are therefore thought to be less ecologically productive and diverse.

\section{References}

Adrain, R. (1991). The feeding behavior of Cyclops kolensis and C. vicinus (Crustacean, Copepoda). Limnologie, 24, 2852-2863.

Barker, K. R. (1985). Nematode extraction and bioassays. pp 19-35 In: Barker, K.R., C.C. Carter, and S.N Sasser (Eds), An advanced treatise on Meloidogyne, Vol. 2. North Carolina State University, Raleigh, North Carolina.

Booth, M. A., Tucker B. J., Allen, G. L, \& Fielder, D. S. (2008). Effect of feeding regime and fish size on weight gain, feed intake and gastric evaluation in juvenile Australian snapper Pagraus auratus. Journal of Agriculture, 282, 100-110. http://dx.doi.org/10.1016/j.aquaculture.2008.06.027

Chatarpaul, L., Robinson, J. B., \& Kaushik, N. K. (1979). Role of tubificid worms on nitrogen transformations in stream sediment. Journal of Fisheries Research Board of Canada, 36, 673-678. http://dx.doi.org/10.1139/f79-098

Fair, P. H., \& Fortner, A. R. (1981). The role of formula feeds and natural productivity in culture of the prawn, Macrobrachium rosenbergii. Aquaculture, 24, 233-243. http://dx.doi.org/10.1016/0044-8486(81)990059-4

Ferris, H., \& Matute, M. M. (2003). Structural and functional succession in the nematode fauna of the soil food web. Applied Soil Ecology, 23, 93-110. http://dx.doi.org/10.1016/S0929-1393(03)00044-1

Ferguson, J. G. (1920). Outlines of Arkansas Geology. Arkansas State Bureau of Mines, Manufactures and Agriculture.

Gardner, W. S., Nalepa, T. F., Quigley, M. A., \& Malczyk, J. M. (1981). Release of phosphorus by certain benthic invertebrates. Canadian Journal of Fisheries and Aquatic Sciences, 38, 978-998. http://dx.doi.org/10.1139/f81-131

Hummon, W. D. (1987). Meiobenthos of the Mississippi headwaters, pp 125-140 In: Bertolani, R (Ed), Biology of Tardigrades. Selected Symposia and Monographs UZI., 1, Mucchi, Modena, Italy.

Johnson, D. D. (2009). Sustaining America's aquatic biodiversity, freshwater snail biodiversity and conservation. Virginia State University. Virginia Cooperative Extension Report, 420-530.

Kisielewski, J. (1986). Freshwater Gastrotricha from raised and transitional peat bogs in Poland. Monografie Fauny Polski, 11, 1-143.

Liang, Y., \& Wang, H. (2001). Energy flow of bellamya aeruginosa in a shallow algal lake, Houhu Lake (Wuhan, China). Chinese Journal of Oceanology and Limnology, 19(3), 233-248.

Matute, M. M., Perschbacher, P. W., \& Newell, A. (2009). Determination of benthic soil conditions using nematodes: Nematode food web conditions of fish ponds in the Lincoln and Desha Counties of Arkansas. Journal of the Arkansas Academy of Science, 63, 131-138.

Nelson, D. R. (2001). Tardigrada, pp 527-550. In Thorp, J. H and A. P. Covich (eds.), Ecology an Classification of North American freshwater invertebrates, $2^{\text {nd }}$ edition. Academic Press, San Diego.

Peng, L., Huang, X., Qian, Y., Wei, Y., \& Ding, G. (2006). Determination and comparison of sludge reduction rates caused by microfauna's predation. Bioresource Technology, 97(6), 854-861.

Perschbacher, P. W., \& Strawn, K. (1984). Depth distribution and composition of macro invertebrate communities in enriched, low-salinity fish culture ponds. Journal of the world mariculture society, 15, 341-354.

Robinson, E. H., \& Rushing, B. (1994). Maximum feeding versus maintenance feeding. The Catfish Journal, 8(11), 23. http://dx.doi.org/10.1300/J028v03n01_06

Rubright, J. S., Harrell., J. L., Holcomb, H. W., \& Parker, J. C. (1981). Response of planktonic and benthic communities to fertilizer and feed applications in shrimp mariculture ponds. Proceedings world mariculture, 12(1), 281-299. http://dx.doi.org/10.1111/j.1749-7345.1981.tb00261.x

Russom, Z., Odihirin, R. A., \& Matute, M. M. (1993). Comparison of population density of plant parasitic and free-living nematodes in earthworm casts and adjacent soils of fallow and cultivated land in S.E Nigeria. Annals of Applied Biology, 123, 331-336. http://dx.doi.org/10.1111/j.1744-7348.1993.tb04095.x 
Scott, H. D, Dixon, B., McKimmey, J. M., Udouj, T. H., \& Johnson, R. L. (1998). Arkansas Soils. Arkansas Agricultural Experimental Station Special Report 187.

Smith, I. M., Cook, D. R., \& Smith, B. P. (2001). Water mites ( Hydrachnida) and other arachnids, pp 345- 357 In: Thorp, J. H and A. P. Covich (eds.), Ecology an Classification of North American freshwater invertebrates, $2^{\text {nd }}$ ed. Academic Press, San Diego. http://dx.doi.org/10.1016/B978-012690647-9/50017-X

Stahl, M. S. (1979). The role of natural productivity and applied feeds in the growth of Macrobrachium rosenbergii. Proceedings world mariculture society, $10, \quad 92-109$. http://dx.doi.org/10.1111/j.1749-7345.1979.tb00010.x

Strayer, D. L., Hunter, D. C., Smith, L. C., \& Borg, C. K. (1994). Distribution, abundance, and roles of freshwater clams ( Bivalvia: Unionidae) in freshwater tidal Hudson River. Freshwater Biology, 31, 239-248. http://dx.doi.org/10.1111/j.1365-2427.1994.tb00858.x

Southerland, D. R., \& Wittrock, D. D. (1986). Surface topography of the brachyuran Argulus appendiculosus Wilson, 1907 as revealed by scanning electron microscopy. Parasitology Research, 17(3), 405-415.

Toutain, F., Villemin, G., Albrecht, A., \& Reisinger, O. (1982). Etude ultrastructurale des processus de biodegradation II: Modele Enchytraeides-litiere de feuillus. Pedobiologia, 23, 145-156.

Walz, N. (1997). Rotifer life history strategies and evolution in freshwater plankton communities, pp119-149 In: Streit, B., Stadler, T., \& Lively C.M. (eds.), Evolutionary ecology of freshwater animals. Birkhauser Verlag, Basel.

Wang, N., Hayward, R. S., \& Noltie, D. B. (1998). Effect of feeding frequency on food consumption, growth, size variation, and feeding pattern of age-0 hybrid sunfish. Aquaculture, 165, 261-267. http://dx.doi.org/10.1016/S0044-8486(98)00266-X

Williamson, C. E., \& Reid, J. W. (2001). Copepoda. Pages 915-954 In: Thorp, J.H and Covich, A.P. (eds.), Ecology an Classification of North American freshwater invertebrates, $2^{\text {nd }}$ edition. Academic Press, San Diego. http://dx.doi.org/10.1016/B978-012690647-9/50023-5

Table 1. Comparison of benthic invertebrate population abundances in fed and unfed freshwater catfish ponds. Values are three months means of $100 \mathrm{~mL}$ benthic samples.

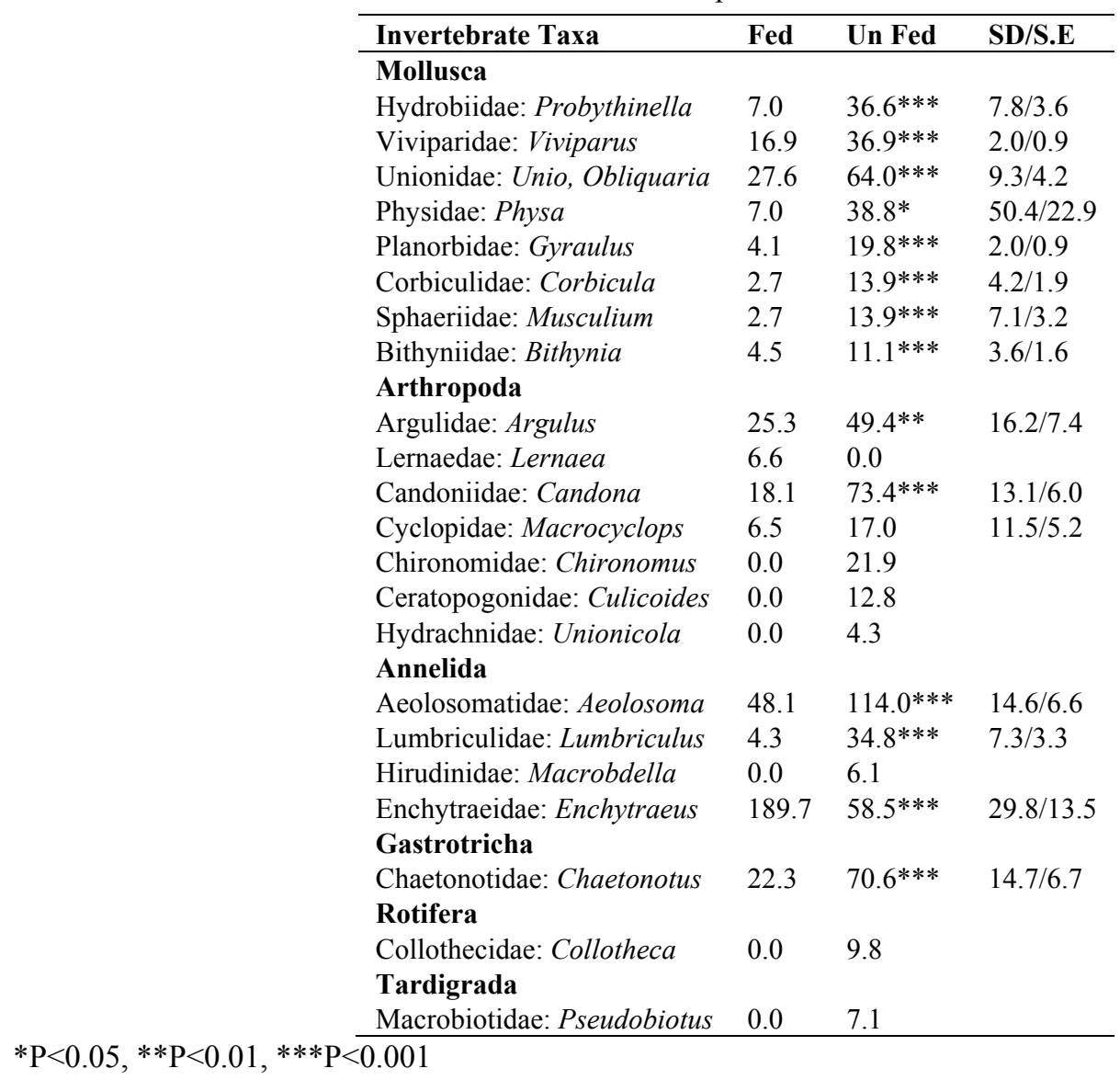

